\title{
The Journal of General Microbiology
}

\author{
Editors: B. C. J. G. KNIGHT and A. F. B. STANDFAST
}

Contents Volume 19, No. 3, December 1958

Uden, N. van, Carmo Sousa, L. Do and Farinha, M. On the intestinal yeast flora of horses, sheep, goats and swine.

Baird-Parker, A. C. and Davis, G. H. G. The morphology of Leptotrichia species.

Taverne, J., Marshall, J. H. and Fulton, F. The purification and concentration of viruses and virus soluble antigens on calcium phosphate.

Hobson, P. N., ManN, S. O. and Oxford, A. E. Some studies on the occurrence and properties of a large Gram-negative coccus from the rumen.

MiLls, R. F. N. The effect of infecting the cells of the de-embryonated egg with influenza virus on their uptake of glucose and amino acids.

Bergersen, F. J. and Briggs, M. J. Studies on the bacterial component of soybean root nodules: cytology and organization in the host tissue.

Sundman, V. and AF BJöRKsten, K. The globular involution forms of the bifid bacteria.

KERRIDGE, D. The effect of actidione and other antifungal agents on nucleic acid and protein synthesis in Saccharomyces carlsbergensis.

HOPTON, J. W. The differential effect of temperature on gas production by a coliform organism.

Morgan, W. J. B. The sensitivity of Vibrio fetus to Streptomycin and the emergence of resistant mutants.

Catlin, B. W. and Cunningham, L. S. Studies of extracellular and intracellular bacterial deoxyribonucleic acids.

Perkins, F. T. A ready reckoner for the calculation of geometric mean antibody titres.

SACKs, L. E. and Pence, J. W. The influence of $\mathrm{pH}$ on the antibacterial action of subtilin A.

SNeAth, P. H. A. and Cowan, S. T. An electro-taxonomic survey of bacteria.

Norris, K. P. and Greenstreet, J. E. S. On the infra-red absorption spectrum of Bacillus megaterium.

MenNA, M. E. Di. Torulopsis ingeniosa n.sp., from grass leaves.

Williamson, G. M. Dihydrostreptomycin and anaerobiosis-indirect evidence for two sites of action of dihydrostreptomycin.

Schaechter, M., MaAl $\phi E$, O. and KJeldgaArD, N. O. Dependency on medium and temperature of cell size and chemical composition during balanced growth of Salmonella typhimurium.

KJeldgaArd, N. O., MaAl $\phi E, O$. and Schaechter, M. The transition between different physiological states during balanced growth of Salmonella typhimurium.

OxFord, A. E. The nutritional requirements of rumen strains of Streptococcus bovis considered in relation to dextran synthesis from sucrose.

Scott, W. J. The effect of residual water on the survival of dried bacteria during storage.

Groman, N. B. and Memmer, R. Lysogeny and conversion in mitis and mitis-like Corynebacterium diphtheriae.

The subscription rate is 90 s. net per volume of 3 parts. Single parts 35 s. each, plus postage. Two volumes will be issued each year. Orders should be sent to

CAMBRIDGE UNIVERSITY PRESS

BENTLEY HOUSE, 200 EUSTON ROAD, LONDON, N.W.1

Parasitology, 48, 3, 4. 
PARASITOLOGY is published in double issues twice a year. The numbers afterwards are issued in volumes each containing four numbers.

Papers for publication should be sent to Professor D. Kenrn, Molteno Institute, Downing Street, Cambridge. Other communications should be addressed to the University Press, Cambridge.

Papers forwarded to the Editors for publication are understood to be offered to PARASITOLOGY alone, unless the contrary is stated.

Contributors receive fifty copies of their papers free. Additional copies, not exceeding one hundred (except in special cases), may be had at cost price: these should be ordered when the final proof is returned.

The subscription price, payable in advance, is £5 net per volume, post-free (U.S.A. \$17.00), double numbers 55s. net, postage extra (U.S.A. \$9.50). Subscriptions may be sent to any Bookseller, or to The Cambridge University Press, Bentley House, 200 Euston Road, N.W.1.

Enquiries from the U.S.A. should be addressed to the American Branch of the Press at 32 East 57th Street, New York, 22. 


\section{O N T E N T S}

(All rights reserved)

Crorron, H. D. Nematode parasite populations in sheep on lowland farms. IV. The effects of anthelmintic treatment. (With 7 Figures in the Text)

Crofton, H. D. Nematode parasite populations in sheep on lowland farms. V. Further observations on the post-parturient rise and a discussion of its significance. (With 6 Figures in the Text)

Crovton, H. D. Nematode parasite populations in sheep on lowland farms. VI. Sheep behaviour and nematode infections. (With 2 Figures in the Text) . . .

Fostren, R. The effects of trematode metacercariae (Brachylaemidae) on the slugs Milax sowerbii Férussac and Agriolimax reticulatus Müller. (With Plate X) .

Paternson, Nextre F. External features and life cycle of Cucumaricola notabilis nov. gen, et sp., a copepod parasite of the holothurian, Cucumaria. (With 11 Figures in the Text)

Solmax, K. N. Globidium gilruthi (Chatton, 1910) infection in the digestive tract of sheep and goats in Egypt

Gresson, R. A. R. The gametogenesis of the digenetic trematode Sphaerostoma bramae (Müller) Lühe. (With Plates XI and XII)

Foster, R. Infestation of the slugs Milax sowerbii Férussac and Agriolimax reticulatus Muiller by trematode metacercariae (Brachylaemidae). (With 2 Figures in the Text)

Erasmus, David A. Studies on the morphology, biology and development of a strigeid cercaria (Cercaria $X$ Baylis 1930). (With Plate XIII and 6 Figures in the Text) .

Tromas, J. D. Studies on Crepidostomum metoecus (Braun) and C. farionis (Müller), parasitic in Salmo trutta L. and S. salar L. in Britain. (With 10 Figures in the Text)

Termex, J. H. The sheep ked, Melophagus ovinus L. I. Dissemination potential .

Temiex, J. H. The sheep ked, Melophagus ovinus L. II. Keds acquired by a lamb from its mother. (With 5 Figures in the Text) . . . . .

Dasgupta, Biswapati. A new sehizogregarine, Mattesia orchopiae n.sp., in a flea of squirrels in England. (With 14 Figures in the Text)

Rothschmd, Mmram. The bird fleas of Fair Isle. (With 10 Figures in the Text) .

JATN, G. P. On Cercaria mehrai Faruqui, 1930 with notes on its life-history. (With 4 Figures in the Text)

Dasgutta, B. and Mreadeniya, Kamani. The vector of Hepatozoon sciuri . (With 7 Figures in the Text)

McConnachie, Ersperth W. Factors affecting the growth and behaviour of axenic strains of Entamoeba invadens Rodhain, 1934.

LEE, D. L. On the morphology of the male, female and fourth-stage larva (female) of Hammerschmidtiella diesingi (Hammerschmidt), a nematode parasitic in cockroaches. (With 8 Figures in the Text)

LEE, D. L. Digestion in Leidynema appendiculata (Leidy, 1850), a nematode parasitic in cockroaches. (With 4 Figures in the Text) .

Tatchens, R. J. The physiology of digestion in the larvae of the horse bot-fly, Gasterophitus intestinalis (de Geer). (With 8 Figures in the Text) .

Sмrth, Kennemh M. A study of the early stages of infeetion with the tipula iridescent virus. (With Plates XIV-XVII)

Thurston, June P. The effect of immune sera on the respiration of Trypanosoma brucei in vitro. (With 2 Figures in the Text)

ReEs, Gwendoten. A comparison of the structure of the seolex of Bothriocephalus scorpii (Müller 1776) and Clestobothrium crassiceps (Rud. 1819) and the mode of attachment of the scolex to the intestines of the host. (With Plates XVIII and $\mathrm{XIX}$ and 31 Figures in the Text)

Barrex, L. The epidemiology of the infestation of the honeybee, Apis mellifera L. by the mite Acarapis woodi Rennie and the mortality of infested bees. (With 5 Figures in the Text)

Index of Authors .

Index of Subjects.

Printed in Great Britain at the University Press, Cambridge

(Brooke Crutchley, University Printer) 